\title{
Open Source Software vs Proprietary Software
}

\author{
Amandeep Singh \\ Research Scholar \\ Guru Kashi University \\ Talwandi Saboo,Bathinda
}

\author{
R.K Bansal, Ph.D \\ Dean Research \\ Guru Kashi University \\ Talwandi Saboo,Bathinda
}

\author{
Neetu Jha \\ Computer Science Department \\ Army Public School, \\ Mamun Cantt,Pathankot
}

\begin{abstract}
Open source Software is turning into the most remarkable "emerging" sensation of the entire Information Technology panorama, initiating a level of concern just like compared to the first juncture of the Internet. For a long-term the exact level oriented discussion has been whether open source is a remarkable conclusion than Proprietary Software. Today, it is not an inquiry of either/or, yet rather which is an ideal complement a certain endeavor demand. Today's open source vs. Proprietary Software headed discussions frequently fixate note on which model is much better, Instead, present day exchange fixates on what is open source or not. Nevertheless, even as we will demonstrate in this paper, the open source development, sensation is not verifiable new, in the past years, it has emerged with an essential enormous, which has authorized it to get into to the mainstream software marketplace. It furthermore encourages completely new strategies involving actions, which have been casting a system of corporations focused around open source programming development. In Spite Of among these facts, plenty of people suppose that Open source software is a momentary trend within the information technology sector. This paper aim to provide certain insights, suggestions, reference point, to ensure that users can surmise provided all this is actually absurdity or it procure advanced analysis additionally considers.
\end{abstract}

\section{Keywords}

Open Source Software, OSS, Free Software, Proprietary Software,

\section{INTRODUCTION}

Exclusively similar to the personal computer and the Internet, open source software ${ }^{[1]}$ lately grabbed the interest of the press as an absolutely unique thing that unexpectedly made an appearance. There's been an incredible repose on business enthusiasm in the direction of the ability of Open Source Software (OSS) through the recent decades. Open source Software (OSS) is workstation development as their sourcecode is obtained under a license that permits consumers to make use of, modification, as well as improve the product or service, and to redistribute it in fine-tuned or unmodified framework. It is consistently manufactured within an open, community way. Open source Projects, generally, begin as volunteer tasks, and the developer's team usually crosses nationwide restrictions. The ideology powering Open Source Software is shared imparting of information, skills, as well as aptitudes. The influence is that, with the numerous individuals researching the source code, bugs are spotted also adjusted with the astonishing rates. Within this paper, we commence with by simply demonstrating, a concise history of open source software, demonstrating that it has a long convention, and that this legacy is recommended for the perception of the specific components of this particular not really emerging approach of contemplating programming. This document studies, technological competition and big difference between Open Source Software and proprietary software. We contend that the authoritative framework of open-source software, authorized by the sociability of source codes and by the resultant advancement of dedicated communities, is a really crucial hallmark which in turn, alongside comparable, can easily permit open-source programming to conquer preexisting trademarked measures.

\section{SOFTWARE AND ITS PARADIGMATIC}

Software can be right away characterized as the executable code that controls, machine conduct and operations. Software likewise alludes to a full cycle of procedures from fundamental to structural engineering to improve, bundling and dispersing. It is liable for supervising, blending, and managing the individual hardware peripheral of a computer system so that other software and the users of the system see it as a functional unit without having to be concerned with the low-level details of the computational system [10]. There are following Software Paradigmatic

\subsection{Freeware}

Freeware designates to software that anybody can download from the Internet and utilization for free. The term freeware was initially utilized by Andrew Fluegelman within 1982, when he needed to offer a correspondences project named PCTalk. Each one permit is particular to the freeware. Copyright laws are likewise material to Freeware. All the appearance is free. Freeware projects might be circulated free of cost. Freeware is free, and is secured by copyright. You can't offer freeware programming and altered programming must be freeware.

\subsection{Shareware}

Sharewares give clients an opportunity to attempt the product before purchasing it. Copyright laws additionally apply to Shareware yet the copyright holder or creator holds all the rights, with a couple of particular exceptions. Most of the times, all peculiarities are not accessible, or have constrained utilization. To utilize all the features of the product, the client needs to buy the software.A shareware might be disseminated uninhibitedly. As a rule, creator's consent is required, to disseminate the shareware. Shareware can't be changed, and it may be either a chop down or impermanent variant.

\subsection{Open Source Software}

Open source software can be defined as software distributed under a licensing agreement which allows the source code (computer code) to be shared, viewed and modified by other users and organizations ${ }^{[2]}$. The open source software contains certain criteria such as:
a) Free Distribution Rights
b) Access to Source Code
c) Permission to modify
d) Distribute Modifications 
e) Forbidding Modifications against persons, groups, fields of endeavor ${ }^{[3]}$

\subsection{Proprietary Software}

Proprietary Software is machine programming authorized under the selective trustworthy advantages associated with the copyright holder. Proprietary Software is created by an individual or firm who has privileges of utilizing pre-existing or flourishing brand new equipment to make new programming. The principle character of Proprietary Software is that its source code is dependably kept a mystery from the outside world. Accordingly, the inside structure of exclusive programming will be not revealed. The Confinements on restrictive programming are by and large forced through a report called EULA (End-user license agreement) to which clients will be suspected to concur just before utilizing the programming. It meets expectations, simply like a written agreement of good use, ailments between the client and merchant.

\subsection{Public Domain Software}

The copyright holder gives it to people in general. Subsequently, it is no more copyrighted and limited and accordingly moves towards Open source.

\subsection{Trial Ware}

It is that kind of software which one is restricted as far as the duration of the time to utilization. The client receives the completed form of programs which may be restricted to the use number of days or use a number of times. In the wake of paying and getting enrolled, the client will get limitless access to the utilization and redesigns of that system.

\section{OPEN SOURCE SOFTWARE AND PROPRIETARY SOFTWARE}

Plenty Of people all over the world choose to utilize Proprietary Software instead of Open Source Software mainly because of the misguided judgment that Proprietary Software is preferred underpinned over the open source software. After a few years of promoting both open source software and Proprietary Software, it gets to be obviously recognizable that simply in light of the fact that you pay for Proprietary Software does not imply that encouraging that product is any simpler; indeed, there are a lot of reasons why supporting Open Source Software is genuinely significantly less demanding. We will now focus on the OSS and Proprietary software for the purpose of this paper evaluate OSS and Proprietary software. There has been significant discussion and debate with respect towards pros and cons of open source Software and Proprietary software. Understanding the benefits and pitfalls of both types of applications can support an individual to make a lot more well informed conclusion. The objective of this particular document is usually to provide a better perception of distinctions between open source and closed source (proprietary) software, and the advantages and disadvantages of each to enable a more informed decision making process when it comes to choosing between the two

Table 1- Open Source Software Versus Proprietary Software

\begin{tabular}{|c|c|c|}
\hline Factor & Open Source Software & Proprietary Software \\
\hline Cost & $\begin{array}{l}\text { Open source software is free. This is a vast draw } \\
\text { card, and if your in-house capacities are such that } \\
\text { you can actualize, prepare and help at least expense } \\
\text { to your association it might be an alluring } \\
\text { alternative. Open source software requires a certain } \\
\text { level of specialized skill to oversee content. It is } \\
\text { along these lines vital to take into attention the } \\
\text { expenses acquired once the product is gotten may } \\
\text { be significant unless the assets are now set up to } \\
\text { oversee it }{ }^{[4]} \text {. } \\
\text { Remarkably, open source software vendors are } \\
\text { increasingly charging for add-ons, additional } \\
\text { administrations and joining. The total cost of } \\
\text { ownership for open source software may generally } \\
\text { equivalent to some jagged source alternatives } \\
\text { consequently. Associations can utilize this } \\
\text { framework as long as they like, without having } \\
\text { considering paying any setup, activation, and } \\
\text { annual or monthly subscription charges }{ }^{[5]}\end{array}$ & $\begin{array}{l}\text { The expense of proprietary software will differ from } \\
\text { a couple of thousand to a couple hundred thousand } \\
\text { Rupees (INR), contingent upon the multifaceted } \\
\text { nature of the framework needed. } \\
\text { This expense is comprised of a base charge for } \\
\text { programming, combination and administrations and } \\
\text { yearly permitting/help charges. This expense may be } \\
\text { restrictive for some; however, what the client is } \\
\text { paying for being a more tweaked item from a trusted } \\
\text { brand that incorporates larger amounts of security and } \\
\text { usefulness, nonstop advancement, a more prominent } \\
\text { capacity to scale, progressing preparing and packing } \\
\text { and a lower prerequisite for specialized abilities. } \\
\text { With a specific end goal to backing these components } \\
\text { and keep up high accessibility sites, an instrument } \\
\text { must be set up to recover the expenses. As specified } \\
\text { formerly, progressively open source programming } \\
\text { suppliers are moreover charging for additional items, } \\
\text { extra administrations, and combination, lessening the } \\
\text { crevice in cost between the two choices }\end{array}$ \\
\hline $\begin{array}{l}\text { Service and } \\
\text { Support }\end{array}$ & $\begin{array}{l}\text { Administration is one of the key issues with respect } \\
\text { to open source programming. Open source software } \\
\text { depends on its online group system to convey help } \\
\text { by means of discussions forums and blogs. While } \\
\text { there are huge, steadfast and captivated online } \\
\text { groups that clients can turn to, time-poor customers } \\
\text { of today are acquainted with the prompt } \\
\text { administration and help that empowers issues to be } \\
\text { determined in an auspicious way, and these groups } \\
\text { can't promise the abnormal state of responsive. }\end{array}$ & $\begin{array}{l}\text { In the event that the web is a vital channel for an } \\
\text { association, Software is regularly an optional concern, } \\
\text { with administration level and help structure } \\
\text { prerequisites taking a point of reference for } \\
\text { augmenting up-time and minimizing downtime. The } \\
\text { administration is likely the best focal point of utilizing } \\
\text { exclusive programming. Proprietary software } \\
\text { suppliers offer progressing backing to clients, a key } \\
\text { offering point for clients without specialized mastery. }\end{array}$ \\
\hline Innovation & Open source programming empowers innovation & Proprietary software suppliers don't permit clients to \\
\hline
\end{tabular}




\begin{tabular}{|c|c|c|}
\hline & $\begin{array}{l}\text { by furnishing users with the opportunity also } \\
\text { adaptability to adjust the product to suit, without } \\
\text { confinement. } \\
\text { Then again, innovation could conceivably be } \\
\text { passed on to all clients or users of the software. It is } \\
\text { a client's wish whether they wish to impart their } \\
\text { innovation with any online groups, community and } \\
\text { users must be eagerly participating in these groups } \\
\text { to become conscious of such innovation. } \\
\text { It has been deliberated about whether redid } \\
\text { progressions to the original source code limit the } \\
\text { future support and development of the product, as } \\
\text { these can possibly bring about a constrained } \\
\text { capacity to apply future redesigns, fixes or modules } \\
\text { went for enhancing the product, leaving the user } \\
\text { with a form that may have irresolvable issues. } \\
\text { It is important to note that open source software } \\
\text { suppliers generally fight to attract in large scale } \\
\text { R\&D. }\end{array}$ & $\begin{array}{l}\text { view or adjust the source code. While this may be } \\
\text { seen as a hindrance to some, it guarantees the security } \\
\text { and unwavering quality of the product. Moreover, } \\
\text { numerous exclusive programming suppliers customize } \\
\text { software for particular clients to give more } \\
\text { adaptability while putting resources into Research \& } \\
\text { Development to frequently offer new items and } \\
\text { redesigns. } \\
\text { Besides, Proprietary software suppliers have online } \\
\text { client groups that make esteem by imparting thoughts, } \\
\text { procedures and best practices through critical systems, } \\
\text { for example, gatherings and reviews, which likewise } \\
\text { encourage advancement and permit the item to adjust } \\
\text { with evolving needs. This advancement comes } \\
\text { completely tried, and is accessible to all clients on the } \\
\text { product. } \\
\text { It doesn't oblige interest in Research \& development } \\
\text { or the specialized understanding of source code, and } \\
\text { help with execution is by and large piece of the } \\
\text { bundle. } \\
\text { Since merchants must guarantee their product does } \\
\text { not get to be excess, clients likewise profit from the } \\
\text { sort of focused on advancement attempted persistent } \\
\text { interest in R\&D instead of "development for } \\
\text { advancement's purpose", business concentrated } \\
\text { instead of innovation centered }\end{array}$ \\
\hline Usability & $\begin{array}{l}\text { Open source software has been exceptionally } \\
\text { reprimanded for its absence of ease of use. } \\
\text { Generally, the innovation is not inspected by ease } \\
\text { of use specialists and does not gratify to the larger } \\
\text { part of the computer user. } \\
\text { Open source software is generally designer driven, } \\
\text { and without framework organization experience or } \\
\text { the learning needed to control programming } \\
\text { language, utilization of the software and capability } \\
\text { to alter bugs as they emerge is regularly restricted } \\
\text { to those with specialized ability. } \\
\text { Moreover, open source software does not lawfully } \\
\text { oblige documentation, Such as, user manuals or } \\
\text { aides, upsetting the formation of such devices. At } \\
\text { the point when documentation is given, it is } \\
\text { frequently general, containing understood } \\
\text { language, inhibiting learning }{ }^{[4]} \text {. Without adequate } \\
\text { documentation users must depend on option means } \\
\text { such as, online groups, community, discussion } \\
\text { forums, accepting they are able to do, discovering } \\
\text { them and the issue is one others have experienced } \\
\text { or are ready to help resolve. These hindrances are } \\
\text { impediments, yet are not inconceivable }\end{array}$ & $\begin{array}{l}\text { Proprietary software generally makes use of expert } \\
\text { functionality, evaluating, and also as the software } \\
\text { program is frequently geared towards a much more } \\
\text { focused viewers, and as a consequence additional } \\
\text { individualized, usability is usually positioned } \\
\text { extremely high. } \\
\text { In extension, comprehensive user instructions as well } \\
\text { as manuals are supplied. This permits more rapidly } \\
\text { working out and supplies an instantaneous referral, } \\
\text { enabling users to maneuver alongside discovering } \\
\text { curve much more rapidly } \\
\text { Boosting solutions consist of training seminars, } \\
\text { focused courses as well as extended assistance to aid } \\
\text { maximize utilization of the software. It is additionally } \\
\text { very important to keep in mind that even though many } \\
\text { individuals witness proprietary software as "closed", } \\
\text { today's proprietary software comes with a massive } \\
\text { variety of components for the advancement through } \\
\text { alternative techniques as well as developers }\end{array}$ \\
\hline Security & $\begin{array}{l}\text { Open source software is not necessarily developed } \\
\text { in a controlled environment. While big players } \\
\text { often have a concentrated development team, Often } \\
\text { times the software is being developed by } \\
\text { individuals all over the world who may not work } \\
\text { on the software for the duration of its developing } \\
\text { lifetime. } \\
\text { This lack of continuity and common direction can } \\
\text { lead to barriers to effective Communication is } \\
\text { surrounding the software. } \\
\text { It is a well-known fact among security experts that } \\
\text { obscurity leads to security vulnerabilities. In } \\
\text { contrast, open source code is visible for anyone to }\end{array}$ & $\begin{array}{l}\text { Proprietary software is considered much more secured } \\
\text { since it is developed in a governed conditions by their } \\
\text { intensive employees having a frequent direction. } \\
\text { Additionally, the source code may perhaps be } \\
\text { considered as well as modified through this } \\
\text { professionals by itself, additionally is intensively } \\
\text { audited, getting rid of the possibility of back-door } \\
\text { Trojans as well as lowering the threat of any other } \\
\text { bugs or obstacles with the software. }\end{array}$ \\
\hline
\end{tabular}




\begin{tabular}{|c|c|c|}
\hline & $\begin{array}{l}\text { see, leading to more eyes looking for potential } \\
\text { vulnerabilities to be fixed .It is important to } \\
\text { evaluate the ability of an open source community } \\
\text { and or its service providers to respond quickly to } \\
\text { find vulnerabilities. It is worth noting that open } \\
\text { source communities fixed security vulnerabilities } \\
\text { twice as quickly as commercial software vendors } \\
\text { did, according to a recent study by Vera code }\end{array}$ & \\
\hline $\begin{array}{l}\text { Software } \\
\text { Licenses }\end{array}$ & $\begin{array}{l}\text { All software applications require a software license } \\
\text { in order to run. A software license is a legal } \\
\text { instrument that governs how the software can be } \\
\text { used and distributed. The permit for most open- } \\
\text { source programming uses what some have called } \\
\text { copy left. This is a play on the expression } \\
\text { "copyright." To comprehend what this implies, it is } \\
\text { worth considering how open-source programming } \\
\text { could be abused by somebody. Consider that } \\
\text { anyone can download, adjust and convey open- } \\
\text { source programming. What would prevent an } \\
\text { organization from making it form of the product } \\
\text { and afterward begin offering it? That is the place } \\
\text { copy left comes in. The permit for open-source } \\
\text { programming particularly expresses that a client is } \\
\text { not permitted to put limitations on its utilization or } \\
\text { conveyance. Along these lines, by consenting to the } \\
\text { permit, you can't begin offering the product later. } \\
\text { Copy left uses copyright law to make open-source } \\
\text { programming uninhibitedly accessible to be altered, } \\
\text { obliging that all adjusted and stretched out } \\
\text { adaptations are to be free also. The most generally } \\
\text { utilized case of a copy left permit is the GNU } \\
\text { Public License, or GPL. So when you take a gander } \\
\text { at programming and you see that the permit is GPL, } \\
\text { this implies the product is open source }\end{array}$ & $\begin{array}{l}\text { Many proprietary software applications are also } \\
\text { commercial, meaning that you have to pay for a } \\
\text { license. However, many other proprietary software } \\
\text { applications are free. The fact that software is free } \\
\text { does not mean it is not proprietary. In many cases, } \\
\text { software companies have invested many years of } \\
\text { software development into a product. By making the } \\
\text { software proprietary, they are protecting their } \\
\text { investment and make it possible to commercialize } \\
\text { their software. The revenue from software sales can } \\
\text { then be used to continue developing the software. }\end{array}$ \\
\hline Reliability & $\begin{array}{l}\text { Since OSS are accessible on a substantial number } \\
\text { of unconfirmed sites and even most of these } \\
\text { conveyances might be changed by any } \\
\text { technically sound user, all the distributions are } \\
\text { dependable as far as security, heartiness, execution. } \\
\text { The reason is that is a user includes/changes some } \\
\text { segment; it might meets expectations great } \\
\text { exclusively, however, may conflict with different } \\
\text { segments and at last degrade the software. With a } \\
\text { extensive work on its reliability feature ,now Open } \\
\text { source software are considered as a reliable } \\
\text { software. For Example Linux. }\end{array}$ & $\begin{array}{l}\text { Proprietary Software is developed by certain } \\
\text { organizations or perhaps professional teams. } \\
\text { Exclusively accomplished products will likely be } \\
\text { given at the channels. Since there will be no un- } \\
\text { validated alteration, the result is consistently } \\
\text { trustworthy }\end{array}$ \\
\hline Availability & $\begin{array}{l}\text { Open Source Software is freely available over the } \\
\text { net. They are available with } 24 * 7 \text { support from } \\
\text { online community, discussion forums as well. }\end{array}$ & $\begin{array}{l}\text { These will be accessible through their regarded } \\
\text { companies that own the rights to the bundles. Now } \\
\text { and again, the trial version is accessible free of } \\
\text { charge download and testing }\end{array}$ \\
\hline Flexibility & $\begin{array}{l}\text { As organizations continually look to do more with } \\
\text { less, adopting open source software can deliver real } \\
\text { business value - in addition to greater flexibility }{ }^{[12]} \text {, } \\
\text { lower IT costs and increased opportunities for } \\
\text { innovation. Open Source software Increase } \\
\text { Flexibility at a Faster Pace and Lower Cost }\end{array}$ & $\begin{array}{l}\text { When your business uses proprietary software such as } \\
\text { Microsoft Windows and Office, you are on a treadmill } \\
\text { that requires you to keep upgrading both software and } \\
\text { hardware. Updates must be installed for the proper } \\
\text { working ,but not all the updates are flexible with all } \\
\text { versions of the Software's }\end{array}$ \\
\hline
\end{tabular}

\section{WHY TO USE OPEN SOURCE}

\section{SOFTWARE}

Above Comparison is evidence that for a every successful proprietary software we have equivalent or sometime better Open Source Software .Following Table having some examples of Software comparison for some categories 
Table $-2^{[6][13]}$ Alternatives to Proprietary Software

\begin{tabular}{|l|l|l|}
\hline Software Category & Proprietary Software & Equivalent Open Source Software \\
\hline Operating System & Microsoft Windows & Linux Ubuntu \\
\hline Browser & Internet Explorer & Mozila Firefox \\
\hline Office automation & Microsoft Office & Open Office \\
\hline Mathworks & MATLAB & Sci Lab \\
\hline Graphics Tool & Adobe Photoshop & GIMP(GNU Image Manipulation Program \\
\hline Drafting tool & Auto CAD & Archimedes \\
\hline Web Editors & Adobe Dreamweaver & NVU \\
\hline Desktop Publishing & Adobe Acrobat & PDF Creator \\
\hline Blogs & Blogger & WOEDPRESS \\
\hline Mobile & IOS & Android \\
\hline Media Player & Windows Media Player & VLC Player \\
\hline Database & Oracle ,Microsoft SQL Server & My SQL ,Mongo DB,HADOOP \\
\hline Server & Microsoft Window Server & Red Hat Server,Ubuntu Server \\
\hline Web Server & IIS & Apache \\
\hline
\end{tabular}

As We have so many Open Source Software Alternatives Available for the Existing proprietary Software which are equivalent or more reliable ,secure \& flexible which leads to gaining the popularity for Open Source Software

\section{POINTS FOR THE EVOLUTION OF OPEN SOURCE SOFTWARE ${ }^{[14]}$}

Many people in the business world today would like to use proprietary software instead of open source software due to the misconception that proprietary software is better recognized than open source software. ${ }^{[7]}$. Why android operating system based smart phones much more popular, why are Joomla, Drupal, Moodle equally famous to proprietary software just like Sharepoint, Blackboard etc We now go back to the points the institution has to speculate while making a decision about procurement of a total solution. Some critical criteria are.

$\begin{aligned} \text { i. } & \text { Free of Charge Distribution Legal Rights } \\ \text { ii. } & \text { Gain Access To Source Code } \\ \text { iii. } & \text { Authorization to customize } \\ \text { iv. } & \text { Distribute Modifications }{ }^{[8]} \\ \text { v. } & \text { Flexibility } \\ \text { vi. } & \text { Scalability } \\ \text { vii. } & \text { Knowledge base and Self reliance } \\ \text { viii. } & \text { Cost } \\ \text { ix. } & \text { Maintenance/Longevity } \\ x . & \text { Performance } \\ x i . & \text { Usability }\end{aligned}$

\section{WHY TO PREFER OPEN SOURCE SOFTWARE SERVICES ${ }^{[11]}$}

The economic climates and characteristics of open source are persuasive, and the IT industry as a whole will carry on to feature its advantages involving proprietarily professional circumstances. "More than 70 Percent of IT Professionals in the U.S. Prefer Open Source to Proprietary Software for Continuity, Control"[9].An possibility in order to save upon valuable currency exchange. It's estimated that proprietary software purchases costs our country of the order of a billion dollars per annum, many of which goes toward purchase primary software package such as MS Windows and MS Office. This specific could easily be conserved simply by switching over to Linux and a FOSS office suite, such as LibreOffice. In general, FOSS oriented software development keeps the cost low for the developer and the end user and this is most recommended in regards to our IT entrepreneurs, whose primary investment is the idea and the time spen.India has a cost advantage in terms of labour arbitrage. Proprietary software disturbs this cost advantage by impacting massive overheads

\section{CONCLUSION}

It is currently observed that lots of organizations as well as service providers such as IBM, Hewlett Packard are already doing business with all the open source software at the present and it is likely to distribute to many other organizations as well. For These Reasons, the day is not far enough when the software industry will likely experience a great transformation in its application of free software in major as contrasted to that of the proprietary software. In our viewpoint the reality that there exists an option of source codes being exposed to the users has the potential to conquer their guidelines set by the proprietary software and creates its very own specialized niche within the software ecosystem. Thus, concluding by 
expressing there has been a switch over through the Proprietary Software model to the open source software model and it is right here to stay but one major question which arises now is -whether the proprietary software manufacturers should be able to cope up with the obstacles positioned in opposition to them by the OSS and will they have the ability to contend with the OSS?

\section{REFERENCES}

[1] Peter L. Deutsch. Licenses for freely redistributable software. In Proceedings of the First Conference on Freely Redistributable Software, Cambridge, Massachusetts, USA, February 1996

[2] Sam Saltis, "Open Source vs. Closed Source (Proprietary) Software" (Copyright Core DNA 2009)

[3] Mark A Lemley, Robert P. Merges, Peter S. Menell, Intellectual Property in the New Technological Age (4th edn Apen Publishers 2006) 1037.

[4] Sam Saltis, Open Source V/s Closed Source a white paper

[5] http://education-portal.com/academy/lesson/softwarelicensing-proprietary-and-free-and-open-source licenses.html \#lesson

[6] http://ben.balter.com/open-source-alternatives/
[7] http://www.openlogic.com/resources/enterpriseblog/archive/proprietary-software-support-vs-opensource.

[8] http://www.mondaq.com/india/x/278512/IT+internet/

[9] http://community.zimbra.com/zblogs/b/press_releases/ar chive/2014/11/19/more-than-70-percent-of-itprofessionals-in-the-u-s-prefer-open-source-toproprietary-software-for-continuity-control

[10] http://www.openprojects.org/software-definition.htm

[11] Coppola and Neelley (2004), Open Source: A Metaphor for E-Learning

[12] http://www.accenture.com/us-en/Pages/insighttechnology-increase-flexibility-open-source-podcast.aspx

[13] Amandeep Singh, Neetu Jha" Foss :A Challenge to Proprietary Software" IJCST Vo 1. 4, IS Su e3, Ju 1 y- Se pT2013

[14] Amandeep Singh, Neetu Jha" Open Source Software: A Big Leap in the Computer Education" International Journal of Computer Applications $\quad(0975$ Volume 93 - No 6, May 2014 